\title{
Virola sebifera Aubl. (Myristicaceae) leaf chemical composition and implications on leaf-cutter ant foraging choice
}

\author{
Amanda Aparecida Carlos ${ }^{1}$ (1) - Karla da Silva Malaquias ${ }^{2}$ • \\ Rafael Camargo Consolmagno ${ }^{3}$. André Lucio Franceschini Sarria ${ }^{2}$. \\ João Batista Fernandes ${ }^{2} \cdot$ Odair Correa Bueno $^{1}$
}

Received: 2 March 2017 / Accepted: 2 November 2017 / Published online: 9 November 2017

(c) Springer Science+Business Media B.V., part of Springer Nature 2017

\begin{abstract}
Leaf-cutter ant plant material choice is essential for colony maintenance and growth. Plant material is used as a substrate for cultivating symbiotic fungus, and the ants' preference for particular leaves, tends to be determined by vegetal age-related physicochemical factors. The plant species Virola sebifera Aubl. (Myristicaceae), for example, shows a large number of leaf surface trichomes. Although non-glandular, $V$. sebifera trichomes may gradually retain an increasing amount of chemical compounds over the lifetime of the leaf. Thus, the present study aims to investigate the role of plant chemical compounds on Atta sexdens rubropilosa preference for $V$. sebifera leaves of different ages. For this purpose, the chemical composition of trichomes on young and senescent leaves was analyzed, and ants' preference tested. The chemical compositions differ between $V$. sebifera young and senescent leaves, with triacontane (C30) predominance in young leaves and tetratriacontane (C34) predominance in senescent leaves. Ants' preference choice was tested by randomly offering leaves of different ages to A. sexdens rubropilosa workers, following six different
\end{abstract}

Handling Editor: Stanislav Gorb.

Amanda Aparecida Carlos

amandacarlos@yahoo.com.br

1 Centro de Estudos de Insetos Sociais, Universidade Estadual Paulista Júlio de Mesquita Filho (UNESP), Avenida 24A, 1515, Bela Vista, Rio Claro, SP 13506-900, Brazil

2 Centro de Ciências Exatas e de Tecnologia, Departamento de Química, Laboratório de Química de Produtos Naturais, Universidade Federal de São Carlos (UFSCar), Rodovia Washington Luís, Km 235, Caixa Postal 676, São Carlos, SP 13565-905, Brazil

3 Departamento de Botânica, Universidade Estadual Paulista Júlio de Mesquita Filho (UNESP), Avenida 24A, 1515, Bela Vista, Rio Claro, SP 13506-900, Brazil treatments: (1) young leaf fragments; (2) young leaf fragments with few trichomes removed; (3) loose trichomes from young leaves; (4) senescent leaf fragments; (5) senescent leaf fragments with few trichomes removed, and (6) loose trichomes from senescent leaves. Ants' preference was observed for young leaves fragments with a few trichomes removed and also for young leaves loose trichomes. Ants' preference might be due to specific volatile compounds (GLV) preset in V. sebifera young leaves. Results suggest occurrence of ants' selectivity resulting from changes on trichomes chemical composition between $V$. sebifera leaves different age stages.

Keywords Ants preference $\cdot$ Trichomes $\cdot$ Substrate selection $\cdot$ Substrate chemical variation $\cdot$ Plant selection

\section{Introduction}

Leaf-cutter ants colonies rely on obligatory mutualism to grow fungus over plant material, as symbiotic fungus is the major food source for immature ant larvae. However, for adult workers ants, the amount of energy and nutrients derived from fungus as a food source is very low (Bass and Cherrett 1995; Silva et al. 2003). Only 5\% of an adults' energy requirement is derived from symbiotic fungus ingestion. Adult ants, therefore, feed directly on plant sap while cutting out and shredding leaves (Quinlan and Cherrett 1979; Forti and Andrade 1999), or they ingest fluids or tissues from a variety of plant structures (e.g. food bodies and seed elaiosomes; Bueno et al. 2008).

Hence, selection of appropriate plant material by leafcutter ants is essential for colony maintenance and growth, since plant fragments are used as a substrate for cultivating symbiotic fungus. Furthermore, the fact that ants choose a 
variety of plant species or vegetative structures while foraging may guarantee that potential toxic substances do not overload either ants or their symbiotic fungus (Howard et al. 1988). Therefore, plant selection by foraging leaf-cutter ants is a complex process that involves different factors (Verza et al. 2007). The foraging pattern of the genus Atta does not appear to be random, as it is not based on spatial distribution nor on plant material abundance, but rather on plants' attractiveness and repellency. Hence, the ants' preference for particular vegetal material comprises a wide range of characteristics in which chemical composition and leaf content are determinant factors (Howard 1987; Howard et al. 1988; Salatino et al. 1998).

Further research is still needed to determine which factors specifically cause a plant to be chosen by leaf-cutter ants. Although many authors suggest quality and physical characteristics of leaves to be determinant factors (Rockwood 1976; Stradling 1978), others indicate that a plant's chemical compounds may be attractive, inhibitory, or even repellent, (Littledyke and Cherrett 1978; Carlos et al. 2010; Heil 2014). However, researchers are unanimous in highlight the importance of chemical and physical plant features act as the first line of defense against herbivory (Crawley 1983; Marquis et al. 2012). For example, the vegetal species Qualea multifora shows three different and effective defense mechanisms against herbivory during its development: (1) higher number of trichomes during early leaf development; (2) extrafloral nectary activity during mid-phase leaf development; and (3) increase in leaf toughness at advanced developmental stages (Calixto et al. 2015).

Conversely, some specific volatile compounds (GLV) may act as attractive factors for herbivorous species (Heil 2014). Attraction of leaf-cutter ants may be seen as a co-evolutionary relationship as it is also known that plant phenology can be directly influenced by plant-herbivorous interactions (e.g. some species of Malpighiaceae family have considerably reduced leaf areas caused by ants herbivory, although no damage is done to the plants' reproductive structures; Vilela et al. 2014). As postulated from Verza and colleagues (2007), leaf-cutting ants' plant material choice is primarily associated to chemical characteristics of the vegetal substrate. Thus, only after the choice is made, physical factors may play secondary role on leaf-cutting ants' choice. Furthermore, plant age-related factors, such as compound production, reduced water content, increased hardness and leaf nutritional state, are involved in ant selectivity (Stradling 1978; Waller 1986). Howard (1987) described the existence of a positive correlation between quantitative variations in nutrient and water content and ant-workers' foraging choice of substrate. According to this author, plants' secondary compounds production would be an additional variable to contribute to the ants' choice (Howard 1987). Rockwood (1976) emphasizes the importance of chemical compounds on leaf-cutter ants' choice, but adds that seasonal interference on composition of compound and on variation of its quantity should also be taken into consideration.

Many plant species gradually retain an increasing amount of chemical compounds over its lifetime. Compounds found in trichomes are metabolics synthetized within plant cells that may or may not have attached ions directly absorbed from the environment. It is also known that leaf trichomes gradually change the amount and type of chemical compounds they retain as leaves age. For example, the species Virola sebifera Aubl. (Myristicaceae), from Brazilian Cerrado, shows a large number of non-glandular trichomes on leaf surfaces. Increase in chemical compounds retention during $V$. sebifera the leaf lifecycle may be one of the physical features that change considerably in the process of ageing. This indicates that trichome quantity and leaf age could influence cutting-leaf ants preference for $V$. sebifera leaves. The present study aims to investigate the role of plant chemical compounds on Atta sexdens rubropilosa preference for $V$. sebifera in relation to different trichome quantities and leaf ages. Hypotheses tested consisted of checking if (1) presence or low quantity of trichomes and (2) leaves of different ages influenced the foraging preferences of A. sexdens rubropilosa workers. It is expected that the amount of trichomes should be inversely proportional to workers' loading frequency of leaves, as a reduced number of trichomes should stimulate ants' choice; and that ants would show preference for young leaves rather than old ones due to high concentrations of chemical compounds in aged leaves.

\section{Materials and methods}

\section{Bioassay of retained chemical compounds on Virola sebifera Aubl. (Myristicaceae) foliar surface}

Young and senescent $V$. sebifera leaves were collected in the Cerrado area of the Federal University of São Carlos (UFScar, São Carlos, Brazil). Leaves were collected from trees with a mean size of $3 \mathrm{~m}$ height for both chemical analyzes bioassays and behavioral tests. Young leaves were defined as those $16-18 \mathrm{~cm}$ in size, with vivid green color, low leaf stiffness and arranged in the most apical portion of branches. Senescent leaves were defined as those $18-25 \mathrm{~cm}$ in size, with loss of coloration, greater leaf stiffness and from basal parts of branches. The material, separated by foliar ontogeny, was individually packed in plastic bags $(50 \times 70 \mathrm{~cm})$ and immediately transported to the laboratory. Plant species and collected samples were identified by Dr. Leonardo Biral dos Santos, Msc Marcelo Monge Egeã and Msc Rafael Camargo Consolmagno. A voucher specimen (HRCB 57764) was deposited at Herbário Rioclarense (HRCB), Bioscience Institute of São Paulo State University "Júlio de Mesquita 
Filho" (UNESP, Rio Claro, São Paulo). Trichomes from the foliar abaxial face (Fig. 1) were removed by carefully scraping the fresh leaf surface with a blade under a stereomicroscope (Zeiss, Model Stemi 2000), avoiding leaf damage. Some photos of fresh material were also taken using an inverted microscope (Zeiss Model Primovert). A portion of the freshly removed trichomes was sampled for chemical compound identification and quantification.

Chemical analyses were conducted at the Natural Product Chemistry Laboratory of UFSCar Chemistry Department (São Carlos, Brazil). A preliminary test series exploring solvents of different polarities was carried out to choose the most appropriate solvent for extraction. In this test, dichloromethane was found to be the most efficient, and was used in the subsequent analysis. For extraction, $500 \mathrm{mg}$ trichome samples from young leaves and $500 \mathrm{mg}$ trichome samples from senescent leaves were separately mixed with $5 \mathrm{~mL}$ dichloromethane, and each sample was immersed for $30 \mathrm{~s}$ in an ultrasonic bath (Model B14). Obtained extracts were analyzed by gas chromatography combined with mass spectrometry (GC-MS; Shimadzu, Model TQ8040) to determine all compounds present. Ramp rates were $100{ }^{\circ} \mathrm{C}$ for $2 \mathrm{~min}$, $8{ }^{\circ} \mathrm{C} \mathrm{min}^{-1} ; 200{ }^{\circ} \mathrm{C}$ for $5 \mathrm{~min}, 8{ }^{\circ} \mathrm{C} \min ^{-1}$; and $300^{\circ} \mathrm{C}$ for $15 \mathrm{~min}$. Injector and detector temperatures were 320 and $100{ }^{\circ} \mathrm{C}$, respectively (McCaffery and Wilson 1990). Compounds were identified by comparison to standard compounds and ions diagnostic described in literature.

\section{Trichomes morphology analysis of Virola sebifera Aubl (Myristicaceae) young and senescent leaves}

Young and senescent leaf fragments were observed under a scanning electron microscope. Fresh leaf fragments $(1 \mathrm{~cm} \times 1 \mathrm{~cm})$ from leaves of both ages were dehydrated and placed on steel stubs to reach the critical point at which to be coated in gold. Subsequently, each stub sustaining a golden-coated sample was examined and photographed on a scanning electron microscope (Hitachi Model TM 3000).

\section{Behavioral bioassays}

Behavioral bioassays were conducted at the Center for Social Insect Studies (CEIS in the Portuguese acronym), Bioscience Institute of São Paulo State University "Júlio de Mesquita Filho" (UNESP, Rio Claro-SP). Atta sexdens rubropilosa queens were collected during nuptial flight in Edmundo Navarro de Andrade State Forest, municipality of Rio Claro-SP $\left(22^{\circ} 25^{\prime} \mathrm{S}, 47^{\circ} 33^{\prime} \mathrm{W}\right)$. Queen ants were kept in the laboratory (air conditioned room $25^{\circ} \mathrm{C} \pm 2{ }^{\circ} \mathrm{C}$ and $70 \%$ relative humidity) inside plastic containers $(200 \mathrm{~mL})$ with $1 \mathrm{~cm}$ plaster (gypsum) in the bottom for maintaining moisture. Ant colonies started to develop by oviposition of fertilized queens. When colonies increased in size, they were transferred to larger plastic pots $(800 \mathrm{~mL})$, also with $1 \mathrm{~cm}$ bottom plaster layers. Each plastic container was interconnected to two other gypsum-free containers (foraging chamber and depleted material, $500 \mathrm{~mL}$ each) by plastic tubes. For colony maintenance and growth, leaves of Acalypha wilkesiana var. marginata Muell. Arg., Syzygium jambolanum Lam. e Mangifera indica L. were provided daily, ad libitum. Colonies that reached $800 \mathrm{~mL}$ volume of symbiont fungus content were used for preference tests.

Behavioral bioassays were performed using a larger foraging arena connected as replacement for preceding ones (length $28.5 \times$ width $24 \times$ height $5 \mathrm{~cm}$ ). Exposure to new larger foraging arena was made 1 day before behavioral bioassays were conducted so ants could be familiarized to this new environment. Larger foraging arenas were chosen so there was a greater spacing between all substrates to be tested, facilitating visualization of ant
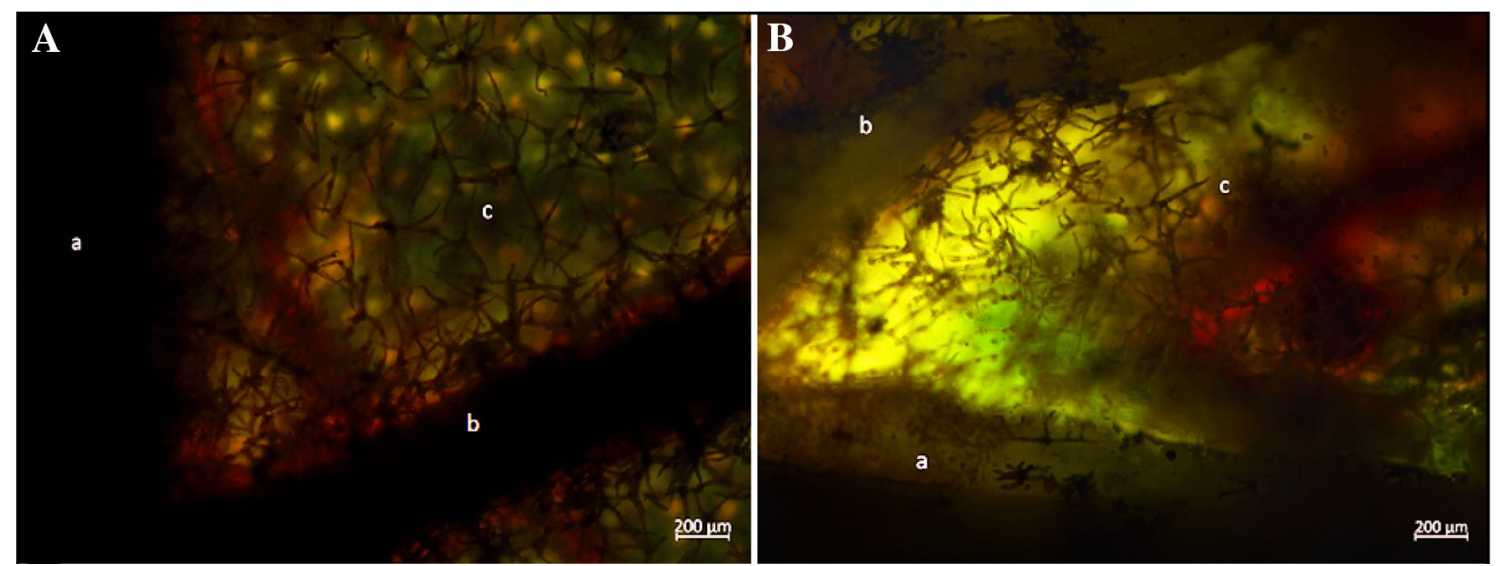

Fig. 1 Stereomicroscope images of Virola sebifera Aubl (Myristicaceae) leaf abaxial faces. A Young leaf, B senescent leaf. $a$ Main leaf vein, $b$ secondary leaf vein, and $c$ leaf blade 
workers' interest in foliar fragments and trichomes. Preference test were performed by suppressing the supply of plant substrate leaves for $24 \mathrm{~h}$ before bioassay. Four different colonies (repetitions) of Atta sexdens rubropilosa (Hymenoptera: Formicidae) were used for the preference choice test. The test was carried out as proposed by Forti et al. (1993), after $24 \mathrm{~h}$ of plant substrate privation.

Behavioral bioassays of preference choice consisted in randomly offering in foraging arenas six treatments of different types of Virola sebifera leaves fragments (five leaf fragments $1.0 \times 1.0 \mathrm{~cm}$ each, cut from different leaves) and a quantity of trichomes ( 2 grams) as substrates per each one of the four colonies. Treatments consisted of (1) young leaf fragments; (2) young leaf fragments with few trichomes removed; (3) loose trichomes from young leaves; (4) senescent leaf fragments; (5) senescent leaf fragments with few trichomes removed, and (6) loose trichomes from senescent leaves; $2 \mathrm{~g}$ of trichomes from senescent leaves. For treatments 2 and 5, trichomes were gently scraped off with a blade under a stereo microscope, avoiding as much mechanical damage to the leaf as possible (Fig. 2). The number of leaf fragments carried by $A$. sexdens rubropilosa workers was determined after $60 \mathrm{~min}$ (treatments 1, 2, 4 and 5). For evaluating interest in trichomes, the presence or absence of ant workers on the offered trichome samples (treatments 3 and 6) was registered every $15 \mathrm{~min}$, totaling $60 \mathrm{~min}$ of experimental time. Afterthe experiment was conducted, all treatments were left in the foraging arena for $24 \mathrm{~h}$ so the total number of $V$. sebifera leaf fragments and trichomes carried by each colony could be determined.

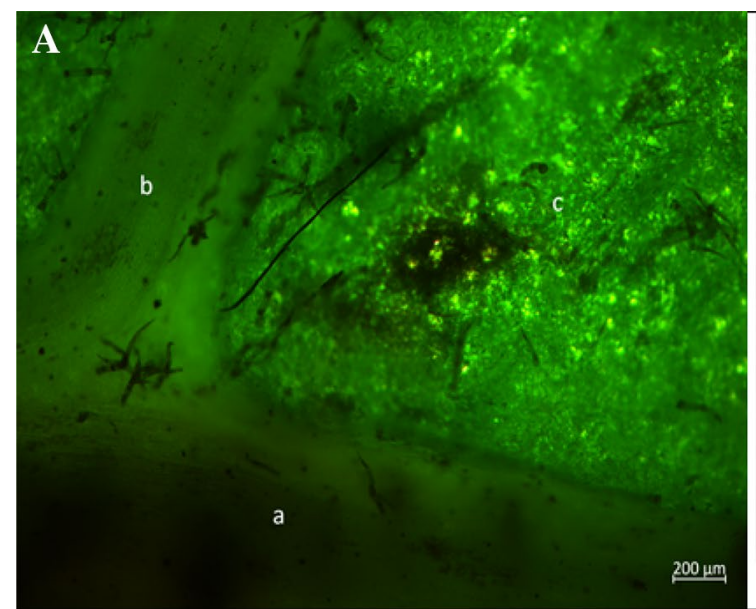

\section{Statistical analysis}

Behavioral bioassays data were analyzed by Kruskal-Wallis analysis $(p \leq 0.05)$. Student-Newman-Keuls test and descriptive statistic (presence and absence) were used on statistical analysis a posteriori (Bioestat 2011).

\section{Results}

\section{Trichomes morphology analysis}

Dendroid trichomes were observed as described by Barthlott et al. (2017). Trichome structures are present on both abaxial and adaxial sides of leaf blades, on both young and senescent leaves. However, the abaxial face shows fewer trichomes in the foliar limbus of both young and senescent leaves. (Fig. 3).

Trichomes present in young leaves were more preserved and uncontaminated, while those present in senescent leaves were mostly brittle (Fig. 4). In addition, a high concentration of organic and inorganic material, such as fungal hyphae, was obsserved adhering to trichomes in senescent leaves (Fig. 4).

\section{Chemical analysis}

The chromatographic method for the determination of the compounds found in trichomes was validated. Linearity and sensitivity were verified and the coefficient of correlation was sufficient for quantification of the compounds $\left(R^{2}: 0.99\right)$. Tables 1 and 2 show the compounds found, which included hydrocarbons, fatty acids and ketones.

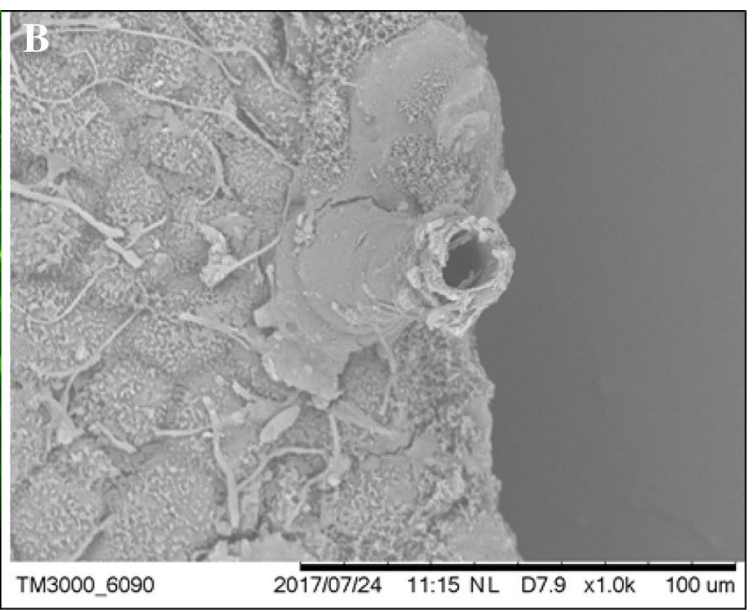

Fig. 2 Scanning electron microscope images of Virola sebifera Aubl. (Myristicaceae) leaf blade abaxial face. A Young leaf abaxial face showing few trichomes after scraping, $\mathbf{B}$ remaining base of a removed trichome, in detail 

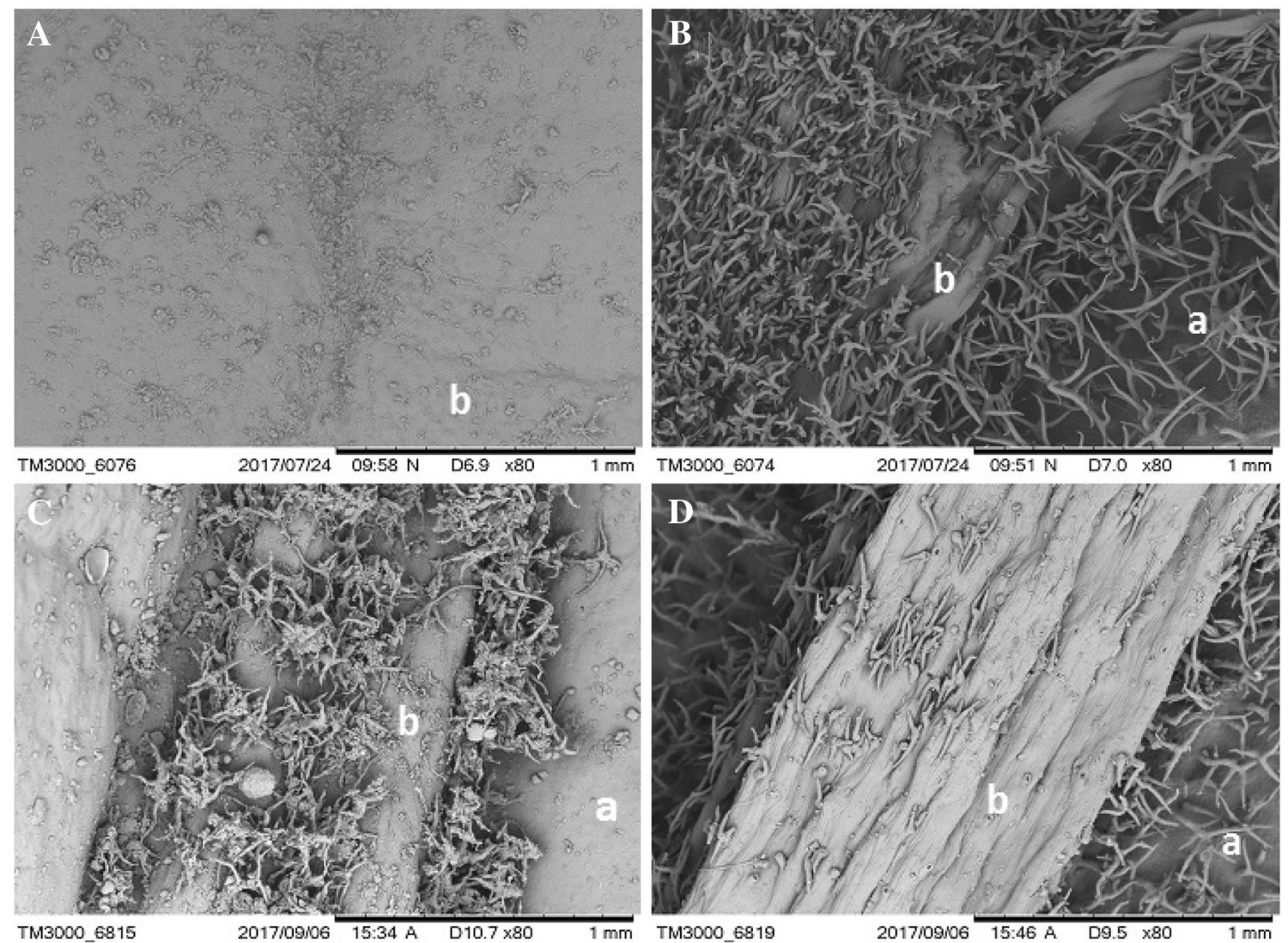

Fig. 3 Scanning electron microscope images of Virola sebifera Aubl (Myristicaceae) leaf. A Young leaf adaxial face, B young leaf abaxial face, $\mathbf{C}$ senescent leaf adaxial face, $\mathbf{D}$ senescent leaf abaxialface. $a$ main leaf vein, $b$ leaf blade

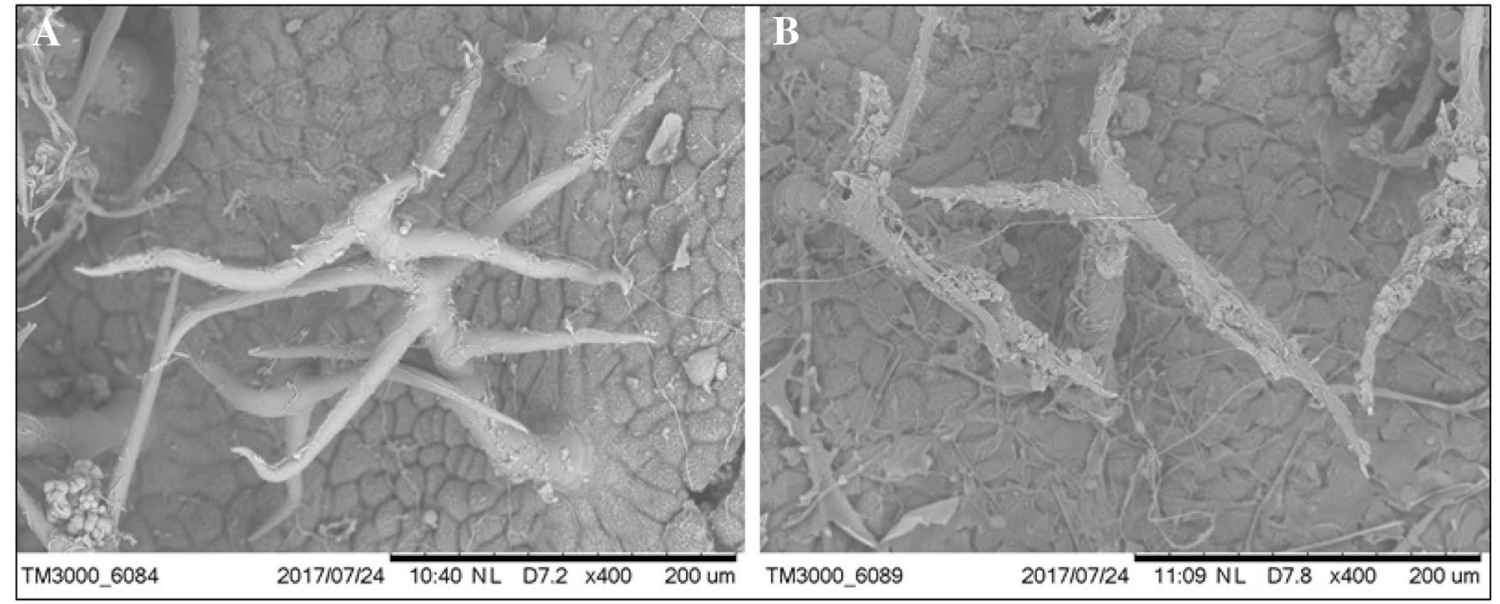

Fig. 4 Scanning electron microscope images of Virola sebifera Aubl. (Myristicaceae). A Young leaf trichomes, B senescent leaf trichomes

\section{Behavioral analysis}

With respect to leaf fragments and trichomes carried to the colonies, Atta sexdens rubropilosa workers carried preferentially young leaf fragments with few trichomes (Treatment
2) within $60 \mathrm{~min}$, and no worker carried senescent leaf fragments (Treatment 4) $(H=8.50 ; p=0.0367)$ (Fig. 5).

Evaluation of ant workers' interest in trichomes over the period of $60 \mathrm{~min}$ in the four repetitions (colonies) showed that ants explored young trichomes more frequently than 
Table 1 Compounds found in the extract of young leaf trichomes

\begin{tabular}{llllc}
\hline $\mathrm{N}$ & RT & Compound & $\mathrm{m} / \mathrm{z}$ & $\begin{array}{c}\text { Concentra- } \\
\text { tion (ppm) }\end{array}$ \\
\hline 1 & 20.063 & Hexadecanoic acid & $60,73,129,256$ & 10.66 \\
2 & 21.989 & Heptadecanoic acid & $60,73,129$ & 1.67 \\
3 & 24.883 & Octacosane (C28) & $57,71,85$ & 1.21 \\
4 & 26.450 & Phytosteroid & - & 16.70 \\
5 & 27.920 & Triacontane & $57,71,85$ & 20.30 \\
6 & 28.081 & 2-Pentacosanone & $135,146,366$ & 4.54 \\
7 & 29.479 & Dotriacontane (C32) & $57,71,85$ & 8.45 \\
\hline
\end{tabular}

$N$ number of the compound obtained, $R T$ retention time (in minute), $\mathrm{m} / \mathrm{z}$ M stands for mass and $\mathrm{Z}$ stands for charge number of ions

Table 2 Compounds found in the extract of senescent leaf trichomes

\begin{tabular}{|c|c|c|c|c|}
\hline $\mathrm{N}$ & RT & Compound & $\mathrm{m} / \mathrm{z}$ & $\begin{array}{l}\text { Concentra- } \\
\text { tion (ppm) }\end{array}$ \\
\hline 1 & 17.790 & o-Toluenesulfonamide & $90,106,171$ & 1.66 \\
\hline 2 & 18.394 & $p$-Toluenesulfonamide & $91,155,171$ & 2.76 \\
\hline 3 & 21.401 & $\begin{array}{l}\text { 3.3.5-Trimethylcy- } \\
\text { clohexyl salicylate }\end{array}$ & $69,138,262$ & 1.06 \\
\hline 4 & 22.250 & Di-octyl ether & $71,113,143$ & 3.29 \\
\hline 5 & 27.297 & Phytosteroid & - & 3.68 \\
\hline 6 & 28.297 & Triacontine & $57,71,85$ & 2.13 \\
\hline 7 & 30.249 & Dotriacontane & $57,71,85$ & 12.02 \\
\hline 8 & 32.069 & Tetratriacontane & $57,71,85$ & 15.64 \\
\hline 9 & 32.260 & 2-Hexacosanone & $135,146,365$ & 1.69 \\
\hline 10 & 33.828 & Hexatriacontane & $57,71,85$ & 7.96 \\
\hline 11 & 36.143 & 1-Heptacosanol & $97,125,139$ & 5.45 \\
\hline
\end{tabular}

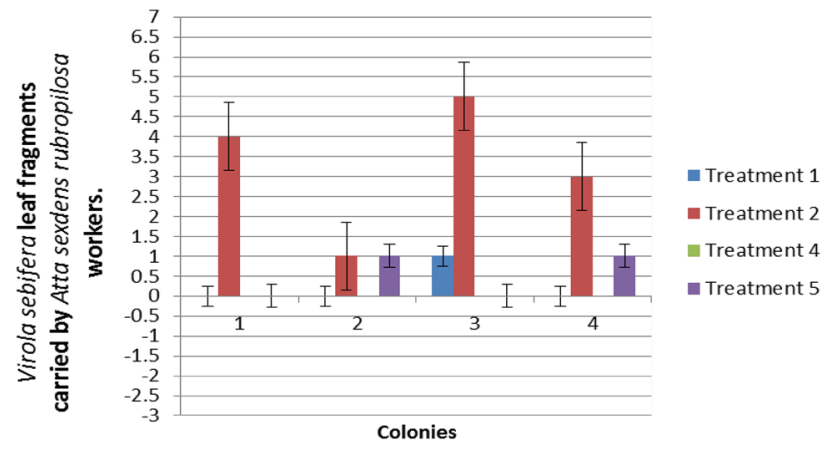

Fig. 5 Percentage of different Virola sebifera leaf fragments carried by Atta sexdens rubropilosa workers. Treatments: 1-young leaf fragments; 2-young leaf fragments with few trichomes; 4-senescent leaf fragments; 5-senescent leaf fragments with few trichomes. Tukey test $(\mathrm{p}=0.05)$. Treatments 3 and 6 were not evaluated because of the difficulty in quantifying the small-sized leaf structures (trichomes)
Table 3 Presence (+) and absence (-) of Atta sexdens rubropilosa workers exploring Virola sebifera trichomes

\begin{tabular}{llllll}
\hline Colony & Trichomes & \multicolumn{4}{l}{ Time (min) } \\
\cline { 3 - 6 } & & 0 & 15 & 30 & 45 \\
\hline 1 & J & + & + & + & + \\
& S & - & - & - & - \\
2 & J & + & + & + & + \\
& S & - & - & + & + \\
3 & J & + & + & + & + \\
& S & - & - & + & + \\
4 & J & + & + & + & - \\
& S & - & - & - & - \\
\hline
\end{tabular}

Trichomes removed from young leaves (Treatment 3) J, Trichomes removed from senescent leaves (Treatment 6) $\mathrm{S}$

old trichomes, irrespective of their position in the foraging arena (Table 3).

After $24 \mathrm{~h}$, senescent leaves with few trichomes remained in the foraging arena. The other leaf fragments were carried and incorporated to symbiotic fungi. Trichomes were still left in the foraging arena. However, due to the small size and color of the structures, it was not possible to visualize their presence or absence on the symbiont under a stereo microscope.

\section{Discussion}

In this study, it could be observed that Atta sexdens rubropilosa workers prefer to carry young $V$. sebifera leaves with few trichomes and showed interest only in young trichomes, ignoring the trichomes of senescent leaves.

The slow speed of carrying the samples may be explained by the conditions of the colonies. Although the colonies had been fasted for $24 \mathrm{~h}$, all had substrate incorporated into the symbiotic fungus from previous feeding. However, characteristics such as fungal volume and estimated number of ants were the same for all colonies. Thus, although the colonies used had been standardized and kept under laboratory conditions, each possessed its own individual characteristics. This obviously influenced the carrying of leaves, as observed in field colonies, which can also vary in activity, being more or less active.

Differences were observed in the compounds present between trichomes of different ages as well as in compounds adhered to them, which could have explained whether the samples were carried to colonies. Analysis of the superfície foliar identified hentriacontane (C31) as the predominant compound in both young and senescent leaves. When comparing ants' loading of these leaves, there was no preference for workers of $A$. sexdens rubropilosa, both were loaded and 
incorporated into the symbiotic fungus (Carlos 2013). In that study, triacontane (C30) was the major chemical compound in young leaves and dotriacontane (C32) in senescent leaves. In contrast, in the present study, a higher concentration of triacontane (C30) was detected in the trichomes of young leaves and of tetratriacontane (C34) in those of senescent leaves.

In plants, the biosynthesis of fatty acids involves a complex enzymatic system in which hydrocarbons are reduced and oxidized, resulting in saturated or unsaturated short-, medium- and long-chain fatty acids. Chemical analysis of the trichomes revealed the presence of these intermediates, with the detection of alcohols, aldehydes and ketones (Tables 2, 3). Substances such as lignans, sesamin, hinokinin and kusunokinin have been detected in crude methanol extracts of $V$. sebifera, in addition to flavonoids in ethyl acetate extracts. The methanol extracts exhibited insecticidal activity against $A$. sexdens rubropilosa (Bicalho et al. 2012). In general, trichomes are described as structures with negative effects, which release exudates that negatively affect insects when they come in contact with the plant (Kogan 1976), thus reducing or impairing the consumption of leaves (Schillinger and Gallum 1968; Singh et al. 1971) by physically damaging insects (Pillemer and Tingey 1978).

For leaf-cutting ants, thick trichomes impair the cutting of leaves (Oliveira et al. 2002). In the present study, workers carried a significant number of young leaves without trichomes. At the beginning, workers whose bodies were impregnated with these trichomes exhibited an a priori cleaning behavior, but accepted these structures over time and apparently did not bother to carry them intentionally, or when they were exploring other samples. On experiments carried by Oliveira et al. (2002), no selectivity was observed in a preference study of Atta bisphaerica testing plants of eight grass species and one legume species. The authors explained this finding by the absence of trichomes or, when present, that they were very thin. As mentioned earlier, trichomes are thin structures in Virola sebifera and, according to these authors, therefore, probably acting as a physical barrier but not influencing plant choice negatively.

However, both the chemical profile and worker behavior suggest that trichomes contribute to attractiveness of plants, regardless of the trichome morphology. The bodies of workers were impregnated with the trichomes of young leaves, but they avoided trichomes collected from senescent leaves, which are morphologically similar. However, senescent leaf trichomes are more damaged than those of young leaves, and the presence of adhered materials is much higher, including fungi hyphae, which could negatively affect both the ant and the fungus that it grows (Fig. 4). Thus, the structural characteristics of both types of trichomes were similar, while the chemical compounds were different, possibly influencing the foraging of these structures by workers.
In addition, worker ants preferentially carried young leaves with few trichomes, possibly to avoid overloading the ants and/or symbionts with a given chemical compound. Another explanation would be the release of compounds that render these leaves more attractive when compared to other treatments. In the first case, the chemical compounds identified as hexadecanoic and heptadecanoic acids are toxic when present in excess, especially to ants (Levin 1987).

However, this could be a very complex response, with workers first evaluating the quality and ideal dosage of compounds on a given substrate. The second, and more likely, hypothesis is that when the trichomes were extracted, even with the greatest possible care, the leaves under this stress released volatile substances of young plants that were perceptible at low concentrations and that could be attractive compounds for the workers. It has already been described that these compounds may indicate the presence of a plant being damaged by herbivores and therefore can also be used by herbivores themselves to locate suitable hosts (Heil 2014). In addition, trichomes collected from senescent leaves contained chemical compounds such as dioctyl ether, 2-hexacosanone and 1-heptacosanol. These compounds result from reactions with hydrocarbons and may be unattractive for workers, with the result that the trichomes are therefore not carried.

In this respect, the presence of some chemical compounds may render the plants attractive to leaf-cutting ants so that they are carried, as observed for leaf fragments with few trichomes, and may cause the exploration of trichomes present on young leaves. It should be noted that this study did not characterize the volatile compounds released by the plants suffering mechanical damage (standardized cutting of leaves offered to the ants) and after the stress caused by removal of the trichomes. These factors probably exerted an important influence on the choice of foraged material.

In conclusion, this study shows how chemical compounds are involved in the selection of plant material, since morphologically similar, but chemically different, trichomes elicit different behavioral responses during foraging of these structures by workers. This occurs even in non-glandular trichomes, such as those of $V$. sebifera, since these structures allow the retention of many substances that adhere to them, whether they originate from the plant itself or from the environment in which it is found. We suggest that a set of factors, i.e., the leaf as a whole including nutrients, volatile compounds and attractive hydrocarbons, define whether or not a plant material is cut and carried by leaf-cutting ants.

Acknowledgements The work was supported by the São Paulo State Foundation to Research (FAPESP, Grant Numbers 2009/17793-8 and 2014/06901-2). The authors would also like to thank Dr. Leonardo Biral dos Santos and Msc Marcelo Monge Egeã for Virola sebifera identification, Dr. Alessandra Ike Coan for methodological support and Msc Mayara Cristina Pereira for photography's of Figure 1 and 2. 


\section{References}

Barthlott W, Mail M, Bhushan B, Koch K (2017) Plant surfaces: structures and functions for biomimetic innovations. Nano-Micro Lett 9:23

Bass M, Cherrett JM (1995) Fungal hyphae as a source of nutrients for the leaf-cutting ant Atta sexdens. Physiol Entomol 20:1-6

Bicalho KU, Terezan AP, Martins DC et al (2012) Evaluation of the toxicity of Virola sebifera crude extracts, fractions and isolated compounds on the nest of leaf-cutting ants. Psyche. https://doi. org/10.1155/2012/785424

Bioestat (2011) Versão 5.3. http://www.mamiraua.org.br/pt-br/ downloads

Bueno OC, Bueno FC, Diniz EA et al (2008) Utilização de alimentos pelas formigas cortadeiras. In: Insetos Sociais da biologia à aplicação. UFV, Viçosa, pp 96-114

Calixto ES, Lange D, Del-Claro K (2015) Foliar anti-herbivore defenses in Qualea multiflora (Vochysiaceae): changing strategy according to leaf development. Flora 212:19-23. https://doi. org/10.1016/j.flora.2015.02.001

Carlos AA (2013). Semioquímicos e comunicação sonora em formigas cortadeiras (Hymenoptera: Formicidae). Universidade Estadual Paulista, Tese

Carlos AA, Rodrigues AS, Forti LC et al (2010) Behavioral Response of the leafcutter ant Atta sexdens rubropilosa (Hymenoptera, Formicidae), to components of citrus pulp. Sociobiology 55(2):1-10

Crawley MJ (1983) Herbivory, the dynamics of animal-plant interactions. Blackwell Science Publications, Oxford

Forti LC, Andrade APP (1999) Ingestão de líquidos por Atta sexdens (L.) (Hymenoptera, Formicidae) durante a atividade forrageira e na preparação do substrato em condições de laboratório. Naturalia 24:61-63

Forti LC, Della Lucia TMC, Yassu WK et al (1993) Metodologias para experimentos com iscas granuladas para formigas cortadeiras. As formigas cortadeiras 13:191-211

Heil M (2014) Herbivore-induced plant volatiles: targets, perception and unanswered questions. New Phytol, 204: 297-306, https://doi. org/10.1111/nph.12977

Howard JJ (1987) Leafcutting ant diet selection: the role of nutrients, water, and secondary chemistry. Ecology 68(3):503-515

Howard JJ, Cazin J Jr, Wiemer DF (1988) Toxicity of terpenoid deterrents to the leaf-cutting Atta cephalotes and its mutualistic fungus. J Chem Ecol 14:59-69

Huwyler S, Grob K Viscontini M (1975) J Insect Physiol 21:299-304

Kogan M (1976) The role of chemical factors in insect/plant relationships. Congr Entomol 15:211-227

Levin DA (1987) The role of trichomes in plant defense. Q Rev Biol 48:3-15
Littledyke M, Cherrett JM (1978) Olfactory responses of the leaf-cutting ants A. cephalotes L) and Acromyrmex octospinosus (Reich.) (Hymenoptera: Formicidae) in the laboratory. Bull Entomol Res 68:273-282

Marquis RJ, Ricklefs RE, Abdala-Roberts L (2012) Testing the low latitude/high defense hypothesis for broad-leaved tree species. Oecologia 169:811-820

McCaffery AR, Wilson ID (eds) (1990) Chromatography and isolation of insect hormones and pheromones. Springer. https://doi. org/10.1007/978-1-4684-8062-7

Oliveira CM, Della Lucia TMC, Nascimento Jr et al (2002) Espécies forrageiras preferidas por Atta bisphaerica FOREL 1908 (Hymenoptera: Formicidae). Rev Ceres 49(283):321-328

Pillemer EA, Tingey WD (1978) Hooked trichomes and resistance of Phaseolus vulgaris to Empoasca fabae (Harris). Entomol Exp Appl 28:83-94

Quinlan RJ, Cherrett JM (1979) The role of fungus in the diet of the leaf-cutting ant Atta cephalotes (L.). Ecol Entomol 4:151-160

Rockwood LL (1976) Plant selection and foraging patterns in two species of leaf-cutting ants (Atta). Ecology 57(1):48-61

Salatino A, Sugayama RL, Negri G et al (1998) Effect of constituents of the foliar wax of Didymopanax vinosum on the foraging activity of the leaf-cutting ant Atta sexdens rubropilosa. Entomol Exp Appl 86:261-266

Schillinger JA, Gallum RL (1968) Leaf pubescence of wheat as a deterrent to the cereal leaf beetle Oulema melanopus. Ann Entomol Soc Am 61:900-903

Silva A, Bacci JrM, Pagnocca FC et al (2003) Survival on Atta sexdens on different food sources. J Insect Physiol 49:307-313

Singh BB, Hadley HH, Bernard RL (1971) Morphology of pubescence in soybeans and its relations to plant vigor. Crop Sci 11:13-16

Stradling DJ (1978) Food and feeding habits of ants. In: Brian MV (ed) Production ecology of ants and termites. Cambridge University Press, Cambridge, pp 81-106

Verza SS, Forti LC, Lopes JF et al (2007) Influence of physical and chemical factors during foraging and culture of the symbiont fungus in Atta sexdens rubropilosa (Hymenoptera: Formicidae). Insect Sci 14:295-300

Vilela AA, Torezan-Silingardi HM, Del-Claro K (2014) Conditional outcomes in ant-plant-herbivore interactions influenced by sequential flowering. Flora 209:359-366. https://doi. org/10.1016/j.flora.2014.04.004

Waller DA (1986) The foraging ecology of Atta texana in Texas. In: Lofgren CE, Vander Meer RK (eds) Fire ants and leaf-cutting ants: biology and management. Westview Press, Boulder and London, pp 146-158 